\title{
Calcium, Zinc, and Iron Bioavailabilities from a Commercial Human Milk Fortifier: A Comparison Study
}

\author{
P. Etcheverry, ${ }^{1}$ J. C. Wallingford, ${ }^{2}$ D. D. Miller, ${ }^{1}$ and R. P. Glahn ${ }^{3}$ \\ ${ }^{1}$ Department of Food Science, Stocking Hall, \\ Cornell University, Ithaca, NY 14853 \\ ${ }^{2}$ Wyeth Nutritionals International, 500 Arcola Rd., \\ Collegeville, PA 19426 \\ ${ }^{3}$ U.S. Plant, Soil, and Nutrition Lab, Tower Road, \\ Cornell University, Ithaca, NY 14853
}

\section{ABSTRACT}

Adding human milk fortifiers (HMF) to human milk (HM) is one way of overcoming the nutrient deficits found in the latter. In this study, the bioavailabilities of calcium, zinc, and iron in S-26/SMA HMF added to HM were compared with those in HM fortified with various bovine milk proteins: $\alpha$-lactalbumin, colostrum, caseinate, casein phosphopeptides, and whey protein concentrate. The bioavailability of each mineral was assessed using an in vitro digestion/Caco-2 cell culture model. Calcium and zinc uptake by the cells was traced with radioisotopes; iron uptake was assessed via cell ferritin levels. Samples were prepared on an equal protein content basis and with added calcium, but no zinc or iron was added. Results revealed that calcium uptake from HM + S-26/SMA was not different from any of the HM fortified with the bovine milk proteins, except for unfortified $\mathrm{HM}$ and $\mathrm{HM}+$ colostrum in which calcium uptake was significantly lower (-89 and $-38 \%$, respectively). Uptake of zinc and iron were significantly higher for HM + S-26/SMA than for the other HM + fortifiers.

(Key words: calcium, zinc, iron, bioavailability)

Abbreviation key: $\mathbf{A A}=$ ascorbic acid, $\mathbf{C P P}=$ casein phosphopeptides, HM = human milk, HMF = HM fortifier, $\mathbf{L S C}=$ liquid scintillation counter, $\mathbf{M E M}=$ minimum essential medium, WPC $=$ whey protein concentrate, $\gamma \mathbf{C}=$ gamma counter.

\section{INTRODUCTION}

One solution to overcoming the nutrient deficits in human milk (HM) for preterm and low birth weight infants is to add a human milk fortifier (HMF) (Lucas, 1993; Schanler, 2001) to expressed milk. The HMF,

Received April 14, 2004.

Accepted June 4, 2004.

Corresponding author: R. P. Glahn; e-mail: rpg3@cornell.edu. which is commercially available in powder and liquid forms, is added to a fixed volume of milk (Galeano and Roy, 1985). In this way, HM is fortified with nutrients, such as proteins, carbohydrates, fat, vitamins, and macro and micro minerals, rather than replaced in its entirety by a formula, such as in the preterm or term infant formulas available in the market. This is very important, as HM provides immunoglobulins, macrophages, lactoferrin, digestive enzymes, growth factors, and hormones that promote growth and development and have a bacteriostatic effect (Sapsford, 2000; Picciano, 2001).

The commercially available HMF in the United States, which first appeared 20 to 25 yr ago, contain bovine whey and whey protein concentrate (WPC) as their main source of added protein (Sapsford, 2000). Although there are many other bovine proteins that could have potential applications in the manufacture of HMF, no studies have been done comparing the effects of those proteins, as fortifiers of HM, on mineral absorption or bioavailability.

The purpose of this study was to compare the calcium, zinc, and iron bioavailabilities from HM containing a commercial fortifier (S-26/SMA HMF; Wyeth Nutritionals International) to the bioavailability of these minerals from HM fortified with different bovine proteins. The current S-26/SMA formulation, which consists of WPC, was compared with colostrum, $\alpha$-lactalbumin, casein phosphopeptides (CPP), caseinate, a combination of these, and WPC. An in vitro digestion/Caco2 cell culture model was used (Glahn et al., 1997, 1998). Calcium and zinc uptake by the cells were traced via radioisotopes, whereas iron uptake was assessed via ferritin formation, a method that has been shown to be a highly sensitive marker of iron bioavailability (Glahn et al., 1998).

\section{MATERIALS AND METHODS}

\section{Cell Cultures}

Caco-2 cells were purchased from the American Type Culture Collection (Rockville, MD). Stock cultures were 
Table 1. Nutritional composition of S-26/SMA human milk fortifier. ${ }^{1}$

\begin{tabular}{lc}
\hline & $\begin{array}{c}\text { Per packet } \\
(2 \mathrm{~g})\end{array}$ \\
\hline Energy, kcal & 7.5 \\
Protein, g & 0.5 \\
Fat, $\mathrm{g}$ & 0.08 \\
Carbohydrate, g & 1.2 \\
Vitamins & \\
Vitamin A, IU & 450 \\
Vitamin D, IU & 150 \\
Vitamin E, IU & 2.3 \\
Vitamin K, $\mu \mathrm{g}$ & 5.5 \\
Thiamin, $\mu \mathrm{g}$ & 113 \\
Riboflavin, $\mu \mathrm{g}$ & 125 \\
Vitamin B,$\mu \mathrm{g}$ & 125 \\
Vitamin $\mathrm{B}_{12}, \mu \mathrm{g}$ & 0.15 \\
Niacin, $\mu \mathrm{g}$ & 1750 \\
Folic acid, $\mu \mathrm{g}$ & 15 \\
Pantothenic acid, $\mu \mathrm{g}$ & 450 \\
Biotin, $\mu \mathrm{g}$ & 0.75 \\
Vitamin C, mg & 20 \\
Minerals & \\
Calcium, mg & 45 \\
Phosphorus, mg & 22.5 \\
Magnesium, mg & 1.5 \\
Iron, mg & $\mathrm{N} / \mathrm{A}^{2}$ \\
Zinc, mg & 0.13 \\
Manganese, $\mu \mathrm{g}$ & 2.3 \\
Copper, $\mu \mathrm{g}$ & $\mathrm{N} / \mathrm{A}$ \\
Sodium, mg & 9 \\
Potassium, mg & 13.5 \\
Chloride, mg & 8.5 \\
\hline & \\
\hline &
\end{tabular}

\footnotetext{
${ }^{1}$ Wyeth S-26/SMA Human Milk Fortifier (Wyeth Nutritionals International).

${ }^{2} \mathrm{~N} / \mathrm{A}=$ Not added to the human milk fortifier (HMF).
}

maintained in Dulbecco's Modified Eagle's Medium ( $\mathrm{pH}$ 7.4) (GIBCO, Grand Island, NY), supplemented with fetal bovine serum (10\% vol/vol) (GIBCO), $25 \mathrm{mmol} / \mathrm{L}$ HEPES (Sigma H-3375, St. Louis, MO), and 1\% antibiotic-antimycotic solution (GIBCO). Cells were cultured at $37^{\circ} \mathrm{C}$ in an incubator with a $5 \% \mathrm{CO}_{2}$ and $95 \%$ air atmosphere at constant humidity. The medium was replaced every $2 \mathrm{~d}$. For uptake experiments, cells (passages 30 to 35 ) were grown in collagen-treated 6-well plates at an initial seeding of $50,000 \mathrm{cells} / \mathrm{cm}^{2}$. Uptake experiments were conducted at $16 \mathrm{~d}$ postseeding.

\section{Sample Preparation}

The nutritional composition of S-26/SMA is shown in Table 1. S-26/SMA contains, among many other nutrients, $0.5 \mathrm{~g}$ protein (WPC), $45 \mathrm{mg}$ calcium, $0.13 \mathrm{mg}$ zinc,

\footnotetext{
*HM + fortifiers will be the general term used to refer to the noncommercial bovine milk proteins added to HM.

$\dagger$ All CPP in this study were from hydrolyzed bovine milk casein. Degree of hydrolysis $(\mathrm{DH})$ was different among the proteins: $\mathrm{CPP}_{\mathrm{A}}$ $\mathrm{DH}=20 \%$ (DMV International Nutritionals); $\mathrm{CPP}_{\mathrm{B}} \mathrm{DH}=16 \%$; and $\mathrm{CPP}_{\mathrm{C}} \mathrm{DH}=20 \%$ (Armor Proteines).
}

$20 \mathrm{mg}$ ascorbic acid (AA)/2 g, and no added iron. S-26/ SMA was added to HM according to the instructions included on the packet, which consisted of dissolving the contents $(2 \mathrm{~g})$ in $50 \mathrm{~mL}$ of $\mathrm{HM}$, providing an additional $4 \mathrm{kcal} / 30 \mathrm{~mL}$. Human milk fortified with the different bovine milk proteins was prepared on an equal protein content basis; thus, an amount of sample containing $0.5 \mathrm{~g}$ of protein was dissolved in $50 \mathrm{~mL}$ of $\mathrm{HM}$. Calcium, in the form of calcium chloride, was added to all HMF, with the exception of S-26/SMA, so that the final calcium content would equal that of S-26/SMA (45 mg). Because calcium was the mineral of primary interest and because there was no intention of fortifying the HMF with zinc or iron, the HM + fortifiers* had no zinc or iron added. The levels present represented the endogenous content.

\section{Description of Fortifiers}

The HM used throughout the study was a pool of unpasteurized samples donated from mothers of fullterm pregnancies, as milk from preterm pregnancies was not available. Bovine colostrum was obtained from GalaGen, Inc. (Minnetonka, MN); $\mathrm{CPP}_{\mathrm{A}}$ was from DMV International Nutritionals (Delhi, NY); $\alpha$-lactalbumin was from Avonmore Foods (Kilkenny, Ireland); $\mathrm{CPP}_{\mathrm{B}}$ and $\mathrm{CPP}_{\mathrm{C}}$ came from Armor Proteines (Saint Brice En Cogles, France); $\dagger$ caseinate came from Bio Serve (Frenchtown, NJ); and, finally, WPC, which was the same WPC used in the S-26/SMA formulation, was obtained from CalPro (Corona, CA).

\section{In Vitro Digestion/Caco-2 Cell Uptake}

The in vitro digestion/Caco-2 cell procedure was conducted over 3 consecutive days. Figure 1 shows a diagrammatic representation of this procedure.

Day 1. The day prior to starting the in vitro digestion, Dulbecco's Modified Eagle's Medium was aspirated from the cells and replaced with $2 \mathrm{~mL}$ of minimum essential medium (MEM; GIBCO). To $6.54 \mathrm{~mL}$ of each fortified $\mathrm{HM}$ sample, $3.46 \mathrm{~mL}$ of $140 \mathrm{mM} \mathrm{NaCl}$ and 5 $\mathrm{m} M \mathrm{KCl}$ were added (total volume $=10 \mathrm{~mL}$ ) in a 50 $\mathrm{mL}$ sterile tube (tube A). Half of this volume was transferred to another 50-mL sterile tube (tube B). To tube A, $12 \mu \mathrm{L}$ of ${ }^{45} \mathrm{Ca}$ (stock $370 \mathrm{MBq} / \mathrm{mL}^{45} \mathrm{CaCl}_{2}$ in $1 \mathrm{~mL}$ $\mathrm{H}_{2} \mathrm{O}$; NEN Life Science Products Inc., Boston, MA) and $2 \mu \mathrm{L}$ of ${ }^{65} \mathrm{Zn}$ (stock $77.46 \mathrm{MBq} / \mathrm{mL}^{65} \mathrm{ZnCl}_{2}$ in $2 \mathrm{~mL}$ of $\mathrm{HCl}$; NEN Life Science Products Inc.) were added and left overnight in the refrigerator to equilibrate with the respective endogenous minerals. The set of radiolabeled A tubes were used for the plates with cells; the set of $\mathrm{B}$ tubes, which contained no radioactive isotope, were used for the companion plates, i.e., 6 -well plates devoid of cells used to study the dialysis of minerals. 


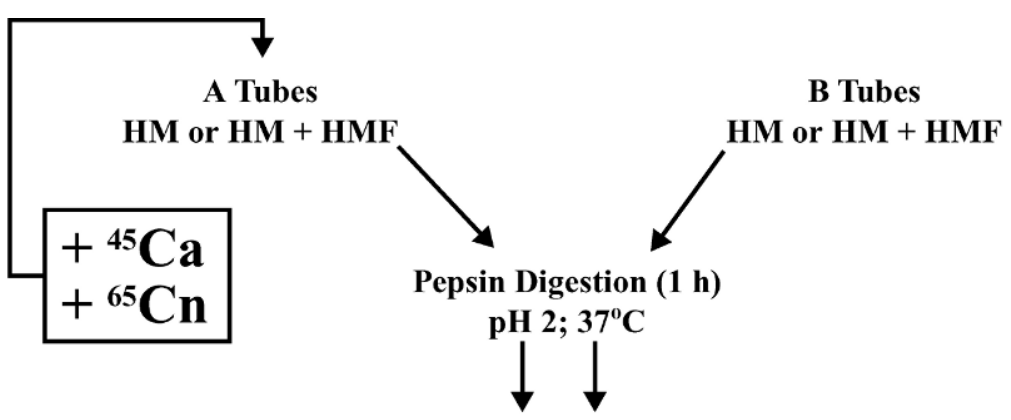

Pancreatin-Bile Digestion (2 h)

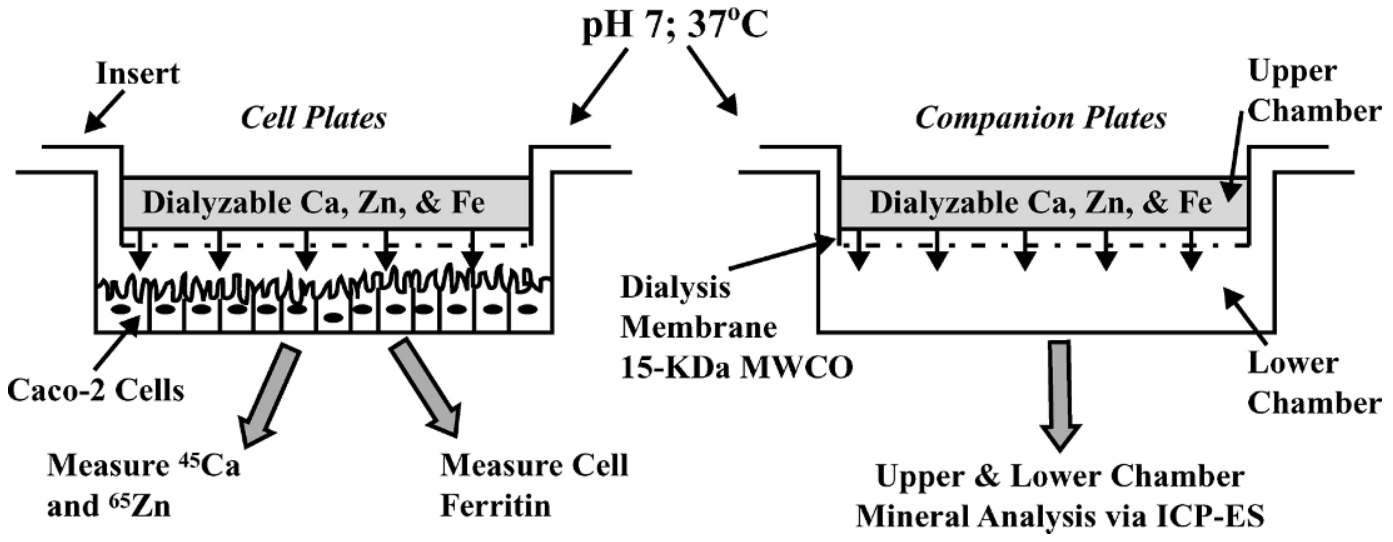

Figure 1. Diagram of in vitro digestion/Caco-2 cell culture model. MWCO = Molecular weight cut off; ICP-ES = inductively coupled argon plasma emission spectrometry.

Day 2. To all tubes, $0.25 \mathrm{~mL}$ of pepsin solution was added after bringing the $\mathrm{pH}$ of the samples down to 2.0 with $1 \mathrm{~N} \mathrm{HCl}$. The pepsin solution consisted of $0.2 \mathrm{~g}$ of pepsin (Sigma P-7000) dissolved in $5 \mathrm{~mL}$ of $0.1 \mathrm{~N} \mathrm{HCl}$. To remove traces of cationic minerals, $2.5 \mathrm{~g}$ of Chelex (an ion exchange resin from BioRad, Hercules, CA) was added. After shaking the enzyme solution for $30 \mathrm{~min}$ in a titer plate shaker (Laboratory-Line Instruments Inc., Melrose, IL), it was poured through a 1.6-cm diameter glass column to remove the resin. The resin was then washed with $5 \mathrm{~mL}$ of $0.1 \mathrm{M} \mathrm{HCl}$, and the eluate, which consisted of the resulting pepsin, was collected. Once the pepsin had been added to the set of tubes, the samples were left in an incubator at $37^{\circ} \mathrm{C}$ for $1 \mathrm{~h}$ on top of a rocker (model RP-50; Laboratory Instruments, Rockville, MD).

Plastic inserts, carrying a dialysis membrane with a molecular weight cutoff of $15,000 \mathrm{Da}$ (Spectra/Por Regenerated Cellulose, Fisher, Pittsburgh, PA), were removed from a $70 \%$ ethanol solution under aseptic conditions and placed in sterilized water to wash away the alcohol. The MEM, placed on top of the cells on $d$ 1 , was aspirated and replaced with $1 \mathrm{~mL}$ of fresh MEM; $1 \mathrm{~mL}$ of this medium was also added to the companion plates. Inserts were then carefully placed in all wells.
Following the 1-h incubation with the pepsin, the samples were brought to $\mathrm{pH} 6.0$ with $1 M \mathrm{NaHCO}_{3}$, and $1.25 \mathrm{~mL}$ of pancreatin/bile solution was added. The pancreatin/bile solution was prepared by dissolving $0.05 \mathrm{~g}$ of pancreatin (Sigma P-1750) and $0.3 \mathrm{~g}$ of bile extract (Sigma B-8631) in $25 \mathrm{~mL}$ of $0.1 \mathrm{M} \mathrm{NaHCO}$, with $12.5 \mathrm{~g}$ of Chelex-100. This pancreatin/bile solution with the ion exchange resin was then poured through a column as described before for the pepsin solution. The resin was washed with $10 \mathrm{~mL}$ of $0.1 \mathrm{M} \mathrm{NaHCO}_{3}$, and the eluate was collected. After the addition of pancreatin/bile solution, the tubes were brought to $\mathrm{pH} 7.0$ with $1 M \mathrm{NaHCO}_{3}$ and brought to a volume of $10 \mathrm{~mL}$ with $140 \mathrm{~m} M \mathrm{NaCl}$ and $5 \mathrm{mM} \mathrm{KCl}$ by weighing the contents of each tube and bringing the final weight to $10 \mathrm{~g}$.

To the upper chamber of each insert, $2.5 \mathrm{~mL}$ of digest was added: radioactive-labeled A tubes were added to the plates with cells, whereas B tubes were added to the companion plates. The plates were then transferred to the incubator at $37^{\circ} \mathrm{C}$ for $2 \mathrm{~h}$ on top of a rocking platform.

Following the 2-h digestion with the pancreatin/bile, the inserts were carefully removed, and an additional $1 \mathrm{~mL}$ of MEM was added to each lower chamber. The 
cell plates were then placed back in the incubator for a further $22 \mathrm{~h}$ ( $24 \mathrm{~h}$ from start of intestinal digestion) to allow time for ferritin formation. The lower chamber contents of the companion plates were transferred to sterile $15-\mathrm{mL}$ tubes and stored in a $-20^{\circ} \mathrm{C}$ freezer for mineral analysis. Tubes labeled A were saved in the refrigerator for upper chamber radioactive count; B tubes, which represent the upper chamber contents, were saved for mineral analysis in a $-20^{\circ} \mathrm{C}$ freezer.

Day 3. Following the 22-h incubation, the media on top of the cells was discarded in a radiolabeled waste container, and the cells were washed $2 \times$ with $2 \mathrm{~mL}$ of $2 \mathrm{~m} M$ EDTA to ensure removal of nonspecific bound ${ }^{45} \mathrm{Ca}$ and ${ }^{65} \mathrm{Zn}$. The cells were sonicated in an Elma Transsonic Digital sonicator (Laboratory-Line Instruments Inc.) for $15 \mathrm{~min}$ at $4^{\circ} \mathrm{C}$ in $2 \mathrm{~mL}$ of $18 \mathrm{M} \Omega$ water. Each well was scraped and mixed to obtain a homogeneous cell suspension. Of the cell suspension, $1.8 \mathrm{~mL}$ was transferred to vials containing $8 \mathrm{~mL}$ of scintillation fluor (Ecoscint, National Diagnostics, Atlanta, GA). Tube A contents were also transferred to vials $(2.5 \mathrm{~mL}$ $+8 \mathrm{~mL}$ of scintillation fluor). Radioactivity was read in a gamma counter $(\gamma \mathrm{C})$ (Packard Auto-Gamma model 5530; Packard Instruments, Downers Grove, IL) and in a liquid scintillation counter (LSC) (Wallac 1410; Pharmacia, Turku, Finland) both under the ${ }^{65} \mathrm{Zn}$ window. The remaining contents of the cell suspension were transferred to microcentrifuge tubes and stored at $-20^{\circ} \mathrm{C}$ for ferritin and cell protein analysis.

\section{Chemical Analyses}

Cell protein. Cell protein was determined using a Bio-Rad DC protein assay kit, based on the Lowry assay.

Mineral content. The upper and lower chamber mineral content was measured via inductively coupled argon plasma emission spectrometry (ICAP model 61E Trace Analyzer; Thermo Jarrell Ash Corporation, Franklin, MA).

Ferritin analysis. Caco-2 cell ferritin was assessed with a one-stage sandwich immunoradiometric assay (FER-IRON II Ferritin Assay; RAMCO Laboratories, Houston, TX).

\section{${ }^{45}$ Calcium and ${ }^{65}$ Zinc Uptake Measurements}

The calcium and zinc measurement has been described in detail elsewhere (Etcheverry et al., 2002). Because the presence of ${ }^{65} \mathrm{Zn}$ in the cell suspension obtained from the in vitro digestion method interfered with the measurement of ${ }^{45} \mathrm{Ca}$ in the LSC but not in the $\gamma \mathrm{C}$, standard curves were constructed to allow the calculation of activity of either isotope in the cell sus- pension. Furthermore, because the presence of cells acted as quenching material, the standard samples were prepared in the presence of cells. Briefly, $16 \mathrm{~d}$ postseeding, Caco-2 cells growing on 6-well plates were sonicated in the presence of $2 \mathrm{~mL}$ of $18 \mathrm{M} \Omega$ water after washing them with $130 \mathrm{mM} \mathrm{NaCl}, 5 \mathrm{mM} \mathrm{KCl}$, and 5 $\mathrm{m} M$ PIPES [1, 4 Piperazine bis (2-ethanosulfonic acid), $\mathrm{pH}$ 6.7]. The sonicated cell suspension was then transferred to vials. Varying amounts of either ${ }^{65} \mathrm{Zn}$ or ${ }^{45} \mathrm{Ca}$ isotope were added and measured in the $\gamma \mathrm{C}$ and/or LSC. To study the quenching caused by the presence of digested samples, the HMF were prepared as described for the in vitro digestion section. Following the 2-h intestinal incubation period, the tubes were stored overnight in a refrigerator. Increasing activity of ${ }^{65} \mathrm{Zn}$ and

${ }^{45} \mathrm{Ca}$ were added to vials containing $2.5 \mathrm{~mL}$ of the digest and $8 \mathrm{~mL}$ of scintillation fluor. ${ }^{65} \mathrm{Zn}$ was measured in the $\gamma \mathrm{C}$ and LSC, but ${ }^{45} \mathrm{Ca}$ was measured only in the LSC.

\section{Experimental Design}

To study the bioavailability of various HMF, 2 studies were conducted. Study 1 consisted of 8 replications, and study 2 consisted of 5 replications. Each replication, which was carried out on separate days, was done in duplicate, meaning that there were 2 sets of 6 -well plates with cells and 2 sets of 6 -well companion plates. The calcium and zinc uptake and the ferritin formation for each replication was the average of 2 wells receiving the same treatment.

\section{Statistical Analysis}

Data was analyzed by one-way ANOVA after testing for normality and equal variance using the Prism software (GraphPad Software, Inc., San Diego, CA). Samples that had unequal variances were logarithmically transformed and analyzed with one-way ANOVA. A Dunnett post test was used to compare the means to the control; a Tukey post test was used to compare pairs of means. Significance was at the level of $P<0.05$.

\section{RESULTS}

The endogenous mineral content of the $\mathrm{HM}+\mathrm{S}-26$ / SMA and HM + fortifiers in the upper chamber and lower chamber are shown in Tables 2 through 4 . According to the manufacturer's nutrition label, the S-26/ SMA powder contains no added Fe (Table 1). However, mineral analysis by inductively coupled argon plasma emission spectrometry revealed some level of Fe $(4 \mu \mathrm{g}$ $\mathrm{Fe} / \mathrm{g}$ of S-26/SMA) probably because of contamination from the rest of the ingredients. When S-26/SMA was mixed with $50 \mathrm{~mL}$ of $\mathrm{HM}$, the resulting $\mathrm{HM}+\mathrm{S}-26 /$ 
Table 2. Calcium content in the upper and lower chambers and percentage dialyzability. ${ }^{1}$

\begin{tabular}{|c|c|c|c|c|}
\hline Sample & $\begin{array}{l}\text { Endogenous } \\
\mathrm{Ca}^{2}\end{array}$ & $\begin{array}{l}\text { Total } \\
\text { upper } \\
\text { chamber } \\
\mathrm{Ca}^{3}\end{array}$ & $\begin{array}{l}\text { Total } \\
\text { lower } \\
\text { chamber } \\
\mathrm{Ca}^{4}\end{array}$ & $\begin{array}{l}\text { Maximum } \\
\text { dialyzed }^{5}\end{array}$ \\
\hline & $(\mu \mathrm{g} / \mathrm{mL})$ & $\longrightarrow$ & 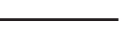 & $(\%)$ \\
\hline $\mathrm{HM}^{6}$ & 184 & 129 & 32.5 & 88.3 \\
\hline HM + S-26/SMA & 1109 & 798 & 53.7 & 23.5 \\
\hline HM + colostrum & 378 & 778 & 46.1 & 20.7 \\
\hline $\mathrm{HM}+\mathrm{CPP}_{\mathrm{A}}^{6}$ & 191 & 765 & 42.4 & 19.4 \\
\hline $\mathrm{HM}+\alpha-\mathrm{LA}$ & 190 & 759 & 42.7 & 19.7 \\
\hline $\mathrm{HM}+$ colostrum $/ \mathrm{CPP} / \alpha-\mathrm{LA}$ & 253 & 768 & 42.2 & 19.2 \\
\hline HM + S-26/SMA & 1102 & 781 & 48.2 & 21.6 \\
\hline $\mathrm{HM}+\mathrm{CPP}_{\mathrm{A}}$ & 197 & 805 & 42.9 & 18.6 \\
\hline $\mathrm{HM}+\mathrm{CPP}_{\mathrm{B}}$ & 201 & 723 & 47.8 & 23.1 \\
\hline $\mathrm{HM}+\mathrm{CPP}_{\mathrm{C}}$ & 195 & 722 & 52.6 & 25.5 \\
\hline $\mathrm{HM}+$ caseinate & 191 & 770 & 43.1 & 19.6 \\
\hline $\mathrm{HM}+\mathrm{WPC}^{6}$ & 249 & 780 & 46.2 & 20.7 \\
\hline
\end{tabular}

${ }^{1}$ The dashed line separates the data obtained from the 2 studies.

${ }^{2}$ Concentration of this mineral in the samples prior to adding $\mathrm{CaCl}_{2}$ and starting the in vitro digestion. $\mathrm{HM}+\mathrm{S}-26 / \mathrm{SMA}$ had the highest calcium content; levels of calcium in the rest of the samples were brought to this concentration. Determined by inductively coupled argon plasma emission spectrometry (ICP-ES).

${ }^{3}$ Amount of calcium in the $2.5 \mathrm{~mL}$ of digested sample placed on the upper chamber of the well at the start of the intestinal digestion period. Determined by ICP-ES.

${ }^{4} \mathrm{Amount}$ of calcium per $1 \mathrm{~mL}$ of dialysate $2 \mathrm{~h}$ past start of intestinal digestion period. These were obtained from companion plates. Determined by ICP-ES.

${ }^{5}$ Total lower chamber $\mathrm{Ca} /$ maximum $\mathrm{Ca}$ that could dialyze $\times 100 \%$. Maximum $\mathrm{Ca}$ that could dialyze $=$ [(total upper chamber $\mathrm{Ca}) /(3.5 \mathrm{~mL})] \times(1.0 \mathrm{~mL})$. Volume of digest in lower chamber of well, $1.0 \mathrm{~mL}$; upper chamber volume $(2.5 \mathrm{~mL})+$ lower chamber volume $(1.0 \mathrm{~mL}), 3.5 \mathrm{~mL}$.

${ }^{6} \mathrm{HM}=$ Human milk, $\mathrm{CPP}=$ casein phosphopeptides, and $\mathrm{WPC}=$ whey protein concentrate.

Table 3. Zinc content in the upper and lower chambers and percentage dialyzability. ${ }^{1}$

\begin{tabular}{|c|c|c|c|c|}
\hline Sample & $\begin{array}{l}\text { Endogenous } \\
\mathrm{Zn}^{2}\end{array}$ & $\begin{array}{l}\text { Total } \\
\text { upper } \\
\text { chamber } \\
\mathrm{Zn}^{3}\end{array}$ & $\begin{array}{l}\text { Total } \\
\text { lower } \\
\text { chamber } \\
\mathrm{Zn}^{4}\end{array}$ & $\begin{array}{l}\text { Maximum } \\
\text { dialyzed }^{5}\end{array}$ \\
\hline & $(\mu \mathrm{g} / \mathrm{mL})$ & $\longrightarrow$ & - & $(\%)$ \\
\hline $\mathrm{HM}^{6}$ & 0.3 & 0.64 & 0.06 & 32.8 \\
\hline HM + S-26/SMA & 2.9 & 2.53 & 0.09 & 12.4 \\
\hline HM + colostrum & 1.5 & 1.87 & 0.08 & 15.0 \\
\hline $\mathrm{HM}+\mathrm{CPP}_{\mathrm{A}}^{6}$ & 0.4 & 0.76 & 0.07 & 32.2 \\
\hline $\mathrm{HM}+\alpha-\mathrm{LA}$ & 0.2 & 0.71 & 0.06 & 29.6 \\
\hline $\mathrm{HM}+$ colostrum $/ \mathrm{CPP} / \alpha-\mathrm{LA}$ & 0.7 & 1.07 & 0.10 & 32.7 \\
\hline HM + S-26/SMA & 3.5 & 2.71 & 0.06 & 7.7 \\
\hline $\mathrm{HM}+\mathrm{CPP}_{\mathrm{A}}$ & 1.0 & 0.86 & 0.04 & 16.3 \\
\hline $\mathrm{HM}+\mathrm{CPP}_{\mathrm{B}}$ & 1.3 & 0.95 & 0.03 & 11.0 \\
\hline $\mathrm{HM}+\mathrm{CPP}_{\mathrm{C}}$ & 1.3 & 0.95 & 0.05 & 18.4 \\
\hline $\mathrm{HM}+$ caseinate & 1.1 & 1.05 & 0.03 & 10.0 \\
\hline $\mathrm{HM}+\mathrm{WPC}^{6}$ & 0.9 & 0.78 & 0.03 & 13.5 \\
\hline
\end{tabular}

\footnotetext{
${ }^{1}$ The dashed line separates the data obtained from the 2 studies.

${ }^{2}$ Concentration of this mineral in the samples prior to starting the in vitro digestion. Determined by inductively coupled argon plasma emission spectrometry (ICP-ES).

${ }^{3}$ Amount of zinc in the $2.5 \mathrm{~mL}$ of digested sample placed on the upper chamber of the well at the start of the intestinal digestion period. Determined by ICP-ES.

${ }^{4} \mathrm{Amount}$ of zinc per $1 \mathrm{~mL}$ of dialysate $2 \mathrm{~h}$ post start of intestinal digestion period. These were obtained from companion plates. Determined by ICP-ES.

${ }^{5}$ Total lower chamber $\mathrm{Zn} /$ maximum $\mathrm{Zn}$ that could dialyze $\times 100 \%$. Maximum $\mathrm{Zn}$ that could dialyze $=$ [(total upper chamber $\mathrm{Zn}) /(3.5 \mathrm{~mL})] \times(1.0 \mathrm{~mL})$. Volume of digest in lower chamber of well, $1.0 \mathrm{~mL}$; upper chamber volume $(2.5 \mathrm{~mL})+$ lower chamber volume $(1.0 \mathrm{~mL}), 3.5 \mathrm{~mL}$.

${ }^{6} \mathrm{HM}=$ Human milk, $\mathrm{CPP}=$ casein phosphopeptides, and $\mathrm{WPC}=$ whey protein concentrate.
} 
Table 4. Iron content in the upper and lower chambers and percentage dialyzability. ${ }^{1}$

\begin{tabular}{|c|c|c|c|c|}
\hline Sample & $\begin{array}{l}\text { Endogenous } \\
\mathrm{Fe}^{2}\end{array}$ & $\begin{array}{l}\text { Total } \\
\text { upper } \\
\text { chamber } \\
\mathrm{Fe}^{3}\end{array}$ & $\begin{array}{l}\text { Total } \\
\text { lower } \\
\text { chamber } \\
\mathrm{Fe}^{4}\end{array}$ & $\begin{array}{l}\text { Maximum } \\
\text { dialyzed }^{5}\end{array}$ \\
\hline & $(\mu \mathrm{g} / \mathrm{mL})$ & $\longrightarrow$ & - & $(\%)$ \\
\hline $\mathrm{HM}^{6}$ & 0.1 & 0.28 & 0.05 & 62.5 \\
\hline $\mathrm{HM}+\mathrm{S}-26 / \mathrm{SMA}$ & 0.4 & 0.44 & 0.09 & 71.6 \\
\hline $\mathrm{HM}+$ colostrum & 0.2 & 0.38 & 0.09 & 82.9 \\
\hline $\mathrm{HM}+\mathrm{CPP}_{\mathrm{A}}^{6}$ & 1.4 & 1.13 & 0.07 & 21.7 \\
\hline $\mathrm{HM}+\alpha-\mathrm{LA}$ & 0.6 & 0.58 & 0.06 & 36.2 \\
\hline $\mathrm{HM}+$ colostrum $/ \mathrm{CPP} / \alpha-\mathrm{LA}$ & 0.7 & 0.65 & 0.17 & 91.5 \\
\hline HM + S-26/SMA & 0.3 & 0.37 & 0.07 & 66.2 \\
\hline $\mathrm{HM}+\mathrm{CPP}_{\mathrm{A}}$ & 1.9 & 1.07 & 0.11 & 36.0 \\
\hline $\mathrm{HM}+\mathrm{CPP}_{\mathrm{B}}$ & 0.2 & 0.35 & 0.07 & 70.0 \\
\hline $\mathrm{HM}+\mathrm{CPP}_{\mathrm{C}}$ & 0.2 & 0.27 & 0.06 & 77.8 \\
\hline HM + caseinate & 0.2 & 0.29 & 0.06 & 72.4 \\
\hline $\mathrm{HM}+\mathrm{WPC}^{6}$ & 0.2 & 0.30 & 0.06 & 70.0 \\
\hline \multicolumn{5}{|c|}{${ }^{1}$ Dashed line separates the data obtained from the two studies. } \\
\hline \multicolumn{5}{|c|}{$\begin{array}{l}{ }^{2} \text { Concentration of this mineral in the samples prior to starting the in vitro digestion. Determined by } \\
\text { inductively coupled argon plasma emission spectrometry (ICP-ES). }\end{array}$} \\
\hline \multicolumn{5}{|c|}{$\begin{array}{l}{ }^{3} \text { Amount of iron in the } 2.5 \mathrm{~mL} \text { of digested sample placed on the upper chamber of the well at the start } \\
\text { of the intestinal digestion period. Determined by ICP-ES. }\end{array}$} \\
\hline \multicolumn{5}{|c|}{$\begin{array}{l}{ }^{4} \text { Amount of iron per } 1 \mathrm{~mL} \text { of dialysate } 2 \mathrm{~h} \text { post start of intestinal digestion period. These were obtained } \\
\text { from companion plates. Determined by ICP-ES. }\end{array}$} \\
\hline \multicolumn{5}{|c|}{$\begin{array}{l}{ }^{5} \text { Total lower chamber Fe/maximum Fe that could dialyze } \times 100 \% \text {. Maximum Fe that could dialyze }=[(\text { total } \\
\text { upper chamber Fe }) /(3.5 \mathrm{~mL})] \times(1.0 \mathrm{~mL}) \text {. Volume of digest in lower chamber of well, } 1.0 \mathrm{~mL} \text {; upper chamber } \\
\text { volume }(2.5 \mathrm{~mL})+\text { lower chamber volume }(1.0 \mathrm{~mL}), 3.5 \mathrm{~mL} \text {. }\end{array}$} \\
\hline
\end{tabular}

SMA had $>1.1 \mathrm{mg}$ of $\mathrm{Ca} / \mathrm{mL}$ (Table 2 ), about $3 \mu \mathrm{g}$ of $\mathrm{Zn} / \mathrm{mL}$ (Table 3) and between 0.3 and $0.4 \mu \mathrm{g}$ of $\mathrm{Fe} / \mathrm{mL}$ (Table 4).

The calcium content for all HM + fortifiers averaged $0.2 \mathrm{mg} / \mathrm{mL}$ except for $\mathrm{HM}+$ colostrum, which was almost $2 \times$ as high $(0.38 \mathrm{mg} / \mathrm{mL})$ (Table 2$)$. Zinc levels (Table 3) were highest for HM + S-26/SMA, because this was the only product with added Zn. For iron, HM $+\mathrm{CPP}_{\mathrm{A}}$ had $10 \times$ more iron than HM $(0.1 \mu \mathrm{g} / \mathrm{mL})$ and over $3 \times$ more iron than HM + S-26/SMA (Table 4 ).

The total upper chamber calcium content, which is the amount of calcium in the $2.5 \mathrm{~mL}$ of digest placed on the upper chamber of each well, was 0.7 to $0.8 \mathrm{mg}$ of calcium for all samples except HM, which was 0.1 mg. All samples except HM had calcium added, so they all had equal levels of this mineral. The percentage of the maximum calcium that dialyzed through the membrane ranged from 18.6 to $25.5 \%$ for all fortified HM samples except for unfortified HM, which was $88.3 \%$ (Table 2). Because the endogenous iron and zinc contents for the minerals were different for all samples and no supplementation with either mineral took place, the total upper chamber zinc and iron contents correlated with the endogenous levels of each mineral.

The calcium and zinc cell uptakes and cell ferritin levels are shown in Figures 2 through 4 . Values are expressed as a percentage of uptakes relative to $\mathrm{HM}+$
S-26/SMA, the control, which was assigned an uptake of $100 \%$. For calcium (Figure 2), HM and HM + colostrum led to significantly lower cell uptake (-89 and $-38 \%$, respectively) than HM + S-26/SMA did. For zinc and iron uptake, all samples were significantly lower than HM + S-26/SMA. Zinc uptake for all samples relative to $\mathrm{HM}+\mathrm{S}-26 / \mathrm{SMA}$ ranged from 6 to $68 \%$ (Figure 3 ), whereas ferritin levels were between 19 and $49 \%$ (Figure 4).

When absolute uptake values were expressed per amount of mineral placed in the upper chamber (Table 5), only $\mathrm{HM}, \mathrm{HM}+$ colostrum, and $\mathrm{HM}+\mathrm{CPP}_{\mathrm{C}}$ were significantly different from HM + S-26/SMA in zinc uptake. For iron, all samples were significantly lower than $\mathrm{HM}+\mathrm{S}-26 / \mathrm{SMA}$ with the exception of HM.

\section{DISCUSSION}

Because HM fails to meet the nutritional requirements of preterm and low birth weight infants, it is not surprising that HMF have been developed since the late 1980s. This study evaluated and compared the calcium, zinc, and iron bioavailabilities of S-26/SMA to other bovine milk proteins. To our knowledge, there are no published studies that simultaneously measure the bioavailability of these 3 minerals. 


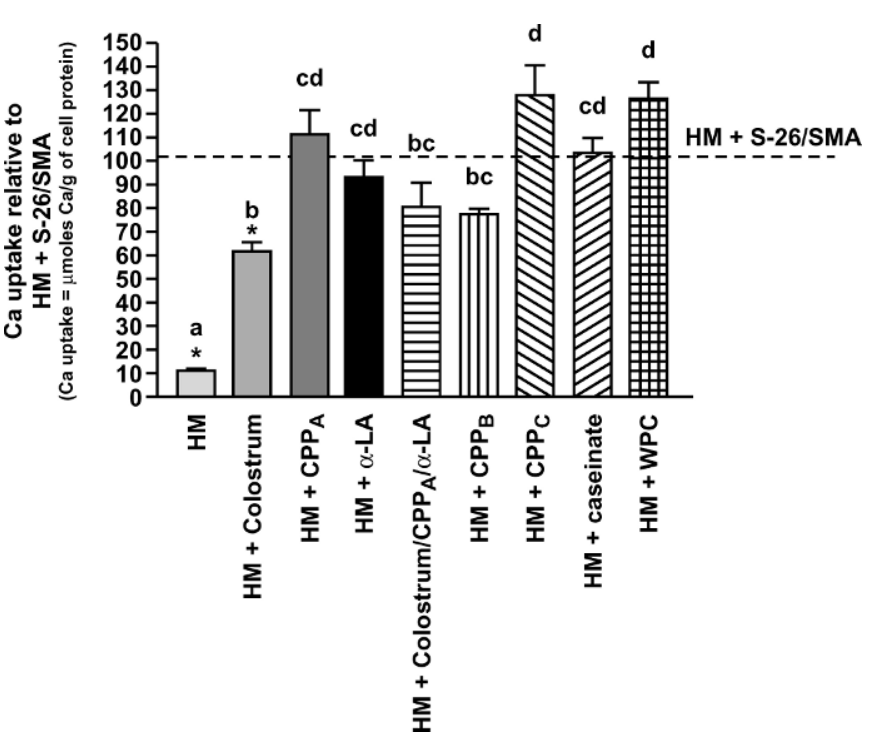

Figure 2. Calcium uptake by Caco-2 cells expressed relative to the control, HM (human milk) + S-26/SMA (assigned a Ca uptake of 100). Bars represent means \pm SEM. Asterisks indicate significant difference compared with the control $(P<0.05)$. Bars with no letters in common are significantly different $(P<0.05)$. CPP $=$ Casein phosphopeptides; WPC $=$ whey protein concentrate.

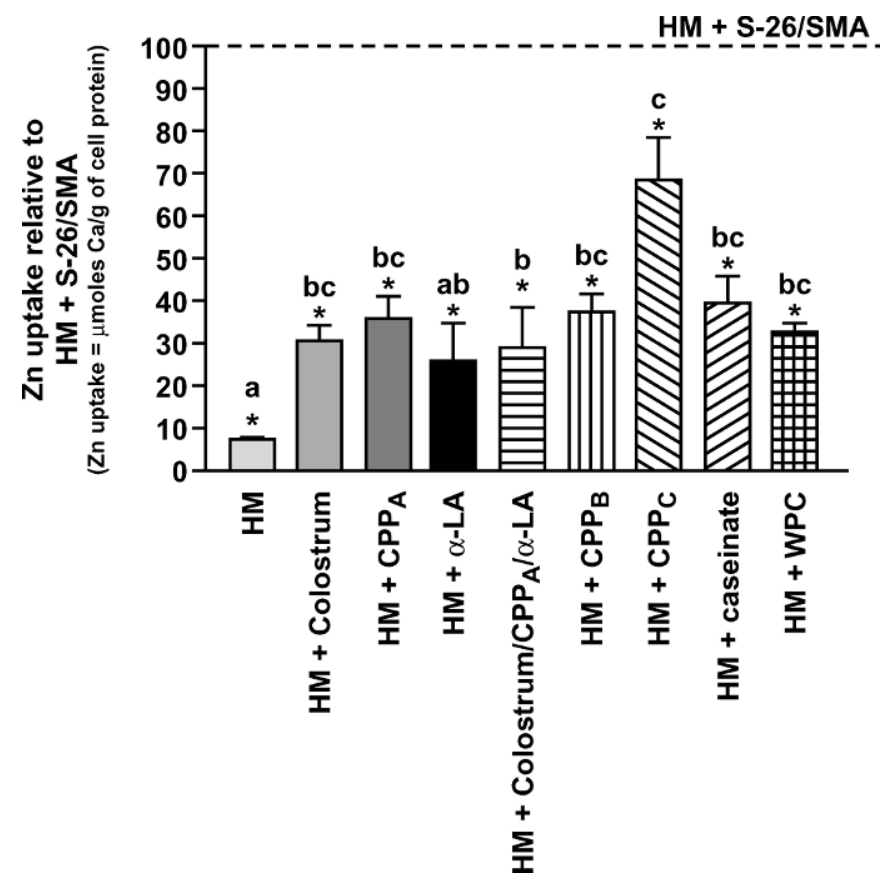

Figure 3. Zinc uptake by Caco-2 cells expressed relative to the control, HM (human milk) + S-26/SMA (assigned a Zn uptake of 100). Bars represent means \pm SEM. Asterisks indicate significant difference compared with the control $(P<0.05)$. Bars with no letters in common are significantly different $(P<0.05) . \mathrm{CPP}=$ Casein phosphopeptides; $\mathrm{WPC}=$ whey protein concentrate.

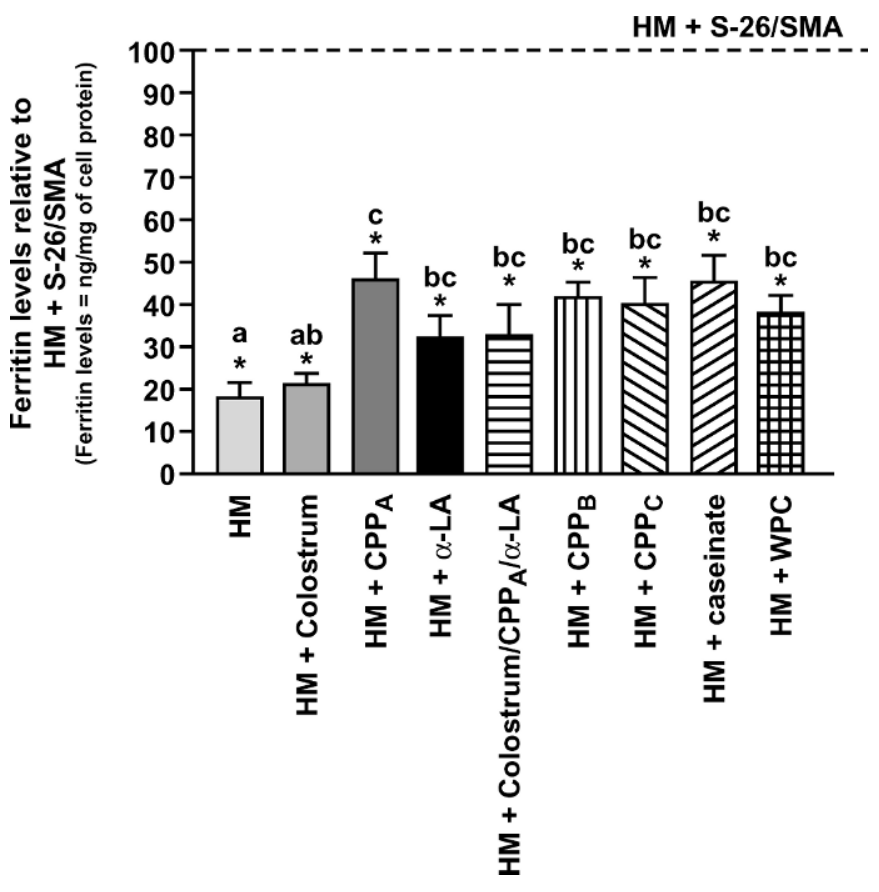

Figure 4. Caco-2 ferritin levels expressed relative to the control, HM (human milk) + S-26/SMA (assigned a ferritin value of 100). Bars represent means \pm SEM. Asterisks indicate significant difference to the control $(P<0.05)$. Bars with no letters in common are significantly different $(P<0.05)$. CPP $=$ Casein phosphopeptides; $\mathrm{WPC}=$ whey protein concentrate.

Calcium uptake from HM + S-26/SMA was not different from any of the HM fortified with the bovine milk proteins, except for HM + colostrum and unfortified $\mathrm{HM}$, in which calcium uptake was significantly lower (Figure 2). The fact that the unfortified HM was lower in calcium uptake than HM + S-26/SMA can simply be explained by lower calcium levels in HM because this was the only sample that did not have any added calcium (Table 2). In the case of HM + colostrum, however, the lower $\mathrm{Ca}$ uptake obtained might be because the mineral was in a form or complex that was not readily bioavailable to the cell, rather than because there was not sufficient calcium present.

Zinc uptake was higher for HM + S-26/SMA than for the other HM + fortifiers (Figure 3). This was not surprising as HM $+\mathrm{S}-26 / \mathrm{SMA}$ had more than $2 \times$ the zinc levels and, thus, more for cell uptake (Table 3). When expressing results relative to the amount of zinc placed on the upper chamber $\left(\right.$ zinc $_{\text {uptake }} /$ zinc $_{\text {upper chamber }}$ contents), all HM + fortifiers, with the exception of HM and $\mathrm{HM}+$ colostrum, were not different from $\mathrm{HM}+\mathrm{S}-$ 26/SMA in zinc uptake (Table 5). Human milk $+\mathrm{CPP}_{\mathrm{C}}$ was even higher than HM + S-26/SMA (Table 5) when zinc uptake results were expressed in this way. This result suggests that the addition of zinc to these non- 
Table 5. Zinc uptake and ferritin levels expressed per amount of zinc and iron present in the upper chamber of the well. Values represent means \pm SEM. Symbols represent significant differences: $* P<0.001 ; \uparrow P<0.05$ to control, HM (human milk) + S-26/SMA. ${ }^{1}$

\begin{tabular}{|c|c|c|}
\hline Sample & $\begin{array}{l}\text { Zn uptake per } \\
\text { upper chamber Zn } \\
\text { content }[(\mu \text { moles Zn } \\
\text { uptake/ } \mu \text { moles } \mathrm{Zn} \\
\text { upper chamber }) \times 100 \%]\end{array}$ & $\begin{array}{l}\text { Ferritin levels } \\
\text { per upper chamber } \\
\text { Fe content }[(\mu \mathrm{g} \\
\text { ferritin } / \mu \mathrm{g} \mathrm{Fe} \\
\text { upper chamber })]\end{array}$ \\
\hline $\mathrm{HM}^{2}$ & $0.42^{*} \pm 0.10$ & $0.35 \pm 0.15$ \\
\hline HM + S-26/SMA & $1.49 \pm 0.30$ & $0.98 \pm 0.37$ \\
\hline $\mathrm{HM}+$ colostrum & $0.59 \dagger \pm 0.10$ & $0.24 \dagger \pm 0.08$ \\
\hline $\mathrm{HM}+\mathrm{CPP}_{\mathrm{A}}^{2}$ & $1.39 \pm 0.23$ & $0.13^{*} \pm 0.05$ \\
\hline $\mathrm{HM}+\alpha-\mathrm{LA}$ & $0.97 \pm 0.27$ & $0.20^{*} \pm 0.06$ \\
\hline $\mathrm{HM}+$ colostrum $/ \mathrm{CPP}_{\mathrm{A}} / \alpha-\mathrm{LA}$ & $0.78 \pm 0.23$ & $0.18^{*} \pm 0.05$ \\
\hline HM + S-26/SMA & $1.02 \pm 0.12$ & $0.63 \pm 0.08$ \\
\hline $\mathrm{HM}+\mathrm{CPP}_{\mathrm{A}}$ & $1.79 \pm 0.24$ & $0.13^{*} \pm 0.01$ \\
\hline $\mathrm{HM}+\mathrm{CPP}_{\mathrm{B}}$ & $1.09 \pm 0.16$ & $0.31^{*} \pm 0.08$ \\
\hline $\mathrm{HM}+\mathrm{CPP}_{\mathrm{C}}$ & $2.00 \dagger \pm 0.36$ & $0.32 * \pm 0.04$ \\
\hline $\mathrm{HM}+$ caseinate & $1.03 \pm 0.19$ & $0.35^{*} \pm 0.05$ \\
\hline $\mathrm{HM}+\mathrm{WPC}^{2}$ & $1.15 \pm 0.15$ & $0.29 * \pm 0.03$ \\
\hline
\end{tabular}

${ }^{1}$ Dashed line separates the data obtained from the two studies.

${ }^{2} \mathrm{HM}=$ Human milk, CPP $=$ casein phosphopeptides, and WPC $=$ whey protein concentrate.

commercial fortifiers might lead to the same or even higher zinc uptake levels than HM + S-26/SMA. However, additional research should be done to confirm this effect.

Iron uptake was higher for HM + S-26/SMA than for the other HM + fortifiers (Figure 4). This was interesting because the Fe contents in the upper chamber were higher for $\mathrm{HM}+\mathrm{CPP}_{\mathrm{A}}$, with more than $3 \times$ the level of iron present in $\mathrm{HM}+\mathrm{S}-26 / \mathrm{SMA}$. It would seem logical, therefore, to predict that $\mathrm{HM}+\mathrm{CPP}_{\mathrm{A}}$ would lead to higher Fe uptake levels, i.e., greater ferritin levels. The high ferritin formation observed in the $\mathrm{HM}+\mathrm{S}-26 / \mathrm{SMA}$ is probably a result of the levels of AA $(20 \mathrm{mg} / 2 \mathrm{~g})$ present in this product. Human milk + S-26/SMA has a total $\mathrm{Fe}$ concentration of 0.3 to $0.4 \mu \mathrm{g} \mathrm{Fe} / \mathrm{mL}$ and, therefore, an AA:Fe molar ratio of 317:1. This ratio may actually be a bit higher considering the contribution of AA from HM itself. The addition of only a 10 -fold molar excess of AA has been shown in our laboratory to enhance ferritin formation greatly in Caco-2 cells (Glahn et al., 2002).

As described before, WPC is the main source of added protein in S-26/SMA, the same one tested in this study. The fact that HM + S-26/SMA was not different compared with HM + WPC in calcium and zinc uptake (the latter expressed as zinc uptake zinc upper chamber ) indicates that there was no net enhancement or inhibition in S26/SMA that affected either of these 2 minerals. On the other hand, ferritin formation in HM + S-26/SMA was significantly higher than that in HM + WPC when expressing results in terms of ferritin levels (Figure 4) or ferritin levels/iron upper chamber $_{\text {(Table 5). Expressing }}$ results relative to upper chamber contents are quite difficult to interpret in the case of iron. This is because iron absorption is strongly influenced by the presence of food components, which can be categorized as iron inhibitors or iron enhancers (Hurrell, 1997). As a result, iron absorption is not only dependent on the iron levels in the food or the upper chamber contents as in our experiment, but also on the quantity, interactions, and equilibrium of the food components mentioned previously.

Addition of AA to these bovine milk proteins would be an interesting comparison, as the presence of the promoter will have different effects on iron bioavailability. Ascorbic acid has been repeatedly shown to be an iron uptake enhancer by reducing ferric iron $\left(\mathrm{Fe}^{3+}\right)$ to ferrous form $\left(\mathrm{Fe}^{2+}\right)$, which is more soluble, as it has a lower tendency than ferric iron to polymerize or form complexes with food components (Miller and Berner, 1989). It is also more bioavailable, as it is the form taken up by the epithelial cells (Han et al., 1995). Even though AA levels were not measured in the bovine fortifiers, they are expected to be very low because they are mostly protein based, and, the only likely source of AA would be HM, which can vary between 80 and $120 \mu \mathrm{g}$ of $\mathrm{AA} / \mathrm{mL}$ of $\mathrm{HM}$ (Lönnerdal, 1997).

Calcium, zinc, and iron in the HM + colostrum were equally dialyzable to that in HM + S-26/SMA (Tables 2 through 4). This result suggests that the minerals in $\mathrm{HM}+$ colostrum are present either unbound or bound to a compound forming a complex that is soluble and small enough to dialyze through the $15-\mathrm{KDa}$ membrane. Although it is soluble and dialyzable, it is a complex that is yet unavailable for the cells to take up. This could due to a very high affinity of the complex 
for the mineral, i.e., a binding affinity higher than that of the intestinal cell receptor for the mineral, which impairs the transfer of the mineral to the cell and to aggregations of different complexes at the brush border region entrapping the mineral and impairing the action of proteolytic enzymes with subsequent release of the mineral.

The milk used throughout this study was not preterm milk, as this milk was not obtainable. Instead the milk used for these experiments constituted a pool of milk from mothers of full-term pregnancies. Preterm milk differs in composition to term milk: it has been reported to contain higher concentrations of protein, fat, and sodium and lower concentrations of lactose, immunoglobulins, and certain macro and micro minerals (Galeano and Roy, 1985; Modanlou et al., 1986; Lucas, 1993). It is hard to predict whether and how the results would have differed if preterm milk had been used instead. It is possible that the levels of calcium uptake could have been lower as lactose promotes calcium absorption. On the other hand, lower levels of protein (in particularly casein) may have enhanced mineral uptake, although the resulting digestion products from casein (CPP) are known to promote mineral absorption.

Obviously, the in vitro digestion/Caco-2 cell culture model will not predict whether the new fortified HM will support growth in the infant. Neither will it answer crucial questions, such as whether these proteins will be well tolerated by the infant, whether they might create metabolic disturbances, promote bone mineralization, and lead to increases in BW and height. However, by using this method as a screening tool, it is possible to identify those bovine proteins that seem most promising in promoting macro and micro mineral absorption, which should have positive effects on infant growth. Certainly future clinical studies involving premature and low birth weight infants will be necessary to confirm the most suitable protein source.

Finally, dialyzability, which requires that compounds be soluble and of molecular weights lower than the dialysis membrane, has been shown to be an incomplete predictor of iron bioavailability (Miller and Berner, 1989). Plotting calcium, zinc, and iron dialyzability vs. absolute cell uptakes gave very low correlation coefficients (data not shown), which emphasizes the impor- tance of combining cultured intestinal epithelial cells (Caco-2 cells) with the in vitro digestion method.

In conclusion, the results indicate that there is no need to change the current S-26/SMA formulation, based on the calcium, zinc, and iron bioavailability results obtained in this study. However, it opens new possibilities of using other proteins such as caseinate, CPP, $\alpha$-lactalbumin, and combinations of these. Colostrum proved not to lead to very bioavailable minerals, although they were soluble and dialyzable.

\section{REFERENCES}

Etcheverry, P., J. C. Wallingford, D. D. Miller, and R. P. Glahn. 2002. Simultaneous determination of ${ }^{45}$ Calcium and ${ }^{65}$ Zinc uptake by Caco-2 cells. J. Agric. Food Chem. 50:6287-6294.

Galeano, N. F., and C. C. Roy. 1985. Feeding the premature infant. Pages 213-228 in Nutrition for Special Needs in Infancy: Protein Hydrolysates. Marcel Dekker, Inc., New York, NY.

Glahn, R. P., Z. Cheng, R. M. Welch, and G. B. Glenn. 2002. Comparison of iron bioavailability from 15 rice genotypes: Studies using an in vitro digestion/Caco-2 cell culture model. J. Agric. Food Chem. 50:3586-3591.

Glahn, R. P., C. Lai, J. Hsu, J. F. Thompson, M. Guo, and D. R. Van Campen. 1997. Decreased citrate improves iron availability from infant formula: Application of an in vitro digestion/Caco-2 cell culture model. J. Nutr. 128:257-264.

Glahn, R. P., O. A. Lee, A. Yeung, M. I. Goldman, and D. D. Miller. 1998. Caco-2 cell ferritin formation predicts nonradiolabeled food iron availability in an in vitro digestion/Caco-2 cell culture model. J. Nutr. 128:1555-1561.

Han, O., M. L. Failla, A. D. Hill, E. R. Morris, and J. C. Smith, Jr. 1995. Reduction of $\mathrm{Fe}$ (III) is required for uptake of nonheme iron by Caco-2 cells. J. Nutr. 125:1291-1299.

Hurrell, R. F. 1997. Bioavailability of iron. Eur. J. Clin. Nutr. 51(Suppl 1):S4-S8.

Lönnerdal, B. 1997. Effects of milk and milk components on calcium, magnesium, and trace element absorption during infancy. Physiol. Rev. 77:643-669.

Lucas, A. 1993. Enteral nutrition. Pages 209-223 in Nutritional Needs of the Preterm Infant: Scientific Basis and Practical Guidelines. Williams and Wilkins, New York, NY.

Miller, D. D., and L. A. Berner. 1989. Is solubility in vitro a reliable predictor of iron bioavailability? Biol. Trace Elem. Res. 19:11-24.

Modanlou, H. D., M. O. Lim, J. W. Hansen, and V. Sickles. 1986. Growth, biochemical status, and mineral metabolism in very low birth weight infants receiving fortified preterm human milk. J. Pediatr. Gastroenterol. Nutr. 5:762-767.

Picciano, M. F. 2001. Nutrient composition of human milk. Pediatr. Clin. North Am. 48:53-67.

Sapsford, A. L. 2000. Human milk and enteral nutrition products. Pages 265-302 in Nutritional Care for High-Risk Newborns, 3rd ed. Precept Press, Inc., IL.

Schanler, R. J. 2001. The use of human milk for premature infants. Pediatr. Clin. North Am. 48:207-219. 